\title{
Role of Physical and Cognitive Factors in Passing Abilities of Futsal Athletes in Universitas Padjadjaran
}

\author{
Leonardo Lubis, ${ }^{1}$ Muhammad Afan Maulana, ${ }^{2}$ Nandina Oktavia ${ }^{1}$ \\ ${ }^{1}$ Division of Anatomy and Cell Biology, Department of Biomedical Sciences Faculty of Medicine \\ Universitas Padjadjaran, Bandung, Indonesia, ${ }^{2}$ Faculty of Medicine Universitas Padjadjaran, Bandung, Indonesia
}

\begin{abstract}
Futsal is a variation of soccer, to be played on a smaller field, with the fastest development among other indoor sports. Futsal players need to master several basic playing techniques to be able to play good futsal, one of them is passing. There are 2 factors that affect futsal athlete skills; physical and mental factors, including cognitive factors. This study aimed to determine the contribution of physical and cognitive factors on the ability to execute passing techniques. A cross-sectional analytic study was conducted in October 2018 on 33 participants who were listed as futsal players in the Faculty of Medicine Futsal Unit, Universitas Padjadjaran, and in the amateur futsal club, La Coruna FC. Physical factor data consisting of body muscle mass percentage, leg muscle percentage, total body fat percentage, and legs subcutaneous fat percentage were measured using Body Impedance Analysis tool while the cognitive factors consisting of; attention, short term memory, and spatial ability, were measured using grid concentration test, digit span test, and spatial ability test, respectively. Athlete's passing ability was measured using 30 second pass and stop test. Data were then analyzed using regression analysis. The results showed that the percentage of leg muscles has the highest significance value for the athlete's passing ability. $(\beta=0.6, p<0.05)$ while the leg muscles percentage and attention level are shown to be the physical and cognitive factors which play greater roles in the passing ability of futsal athletes.
\end{abstract}

Key words: Cognitive factor, futsal, passing ability, physical factor

\section{Peran Faktor Fisik dan Kognitif terhadap Performa Teknik Dasar Passing Atlet Futsal Universitas Padjadjaran}

\begin{abstract}
Abstrak
Futsal adalah variasi sepakbola yang dimainkan di lapangan yang lebih kecil. Atlet futsal perlu menguasai beberapa teknik bermain dasar untuk bermain futsal dan salah satunya adalah passing. Ada 2 faktor yang memengaruhi keterampilan atlet futsal, yaitu fisik dan mental yang salah satunya adalah kognitif. Penelitian ini bertujuan mengetahui kontribusi faktor fisik dan kognitif terhadap kemampuan teknik passing. Studi analitik cross-sectional dilakukan terhadap 33 peserta yang terdiri dari atlet futsal Fakultas Kedokteran dan atlet futsal klub amatir, La Coruna FC selama Oktober 2018 di Jatinangor. Data komponen fisik terdiri atas persentase massa otot tubuh, persentase otot tungkai, persentase lemak tubuh total, dan persentase lemak subkutan kaki yang diukur dengan alat analisis impedansi tubuh, sedangkan kognitif terdiri atas konsentrasi, memori jangka pendek, dan kemampuan spasial yang masing-masing diukur dengan uji konsentrasi grid, uji rentang digit, dan uji kemampuan spasial. Kemampuan passing diukur menggunakan tes pass and stop selama 30 detik. Data kemudian diproses dengan analisis regresi. Hasil Analisis regresi menunjukkan persentase otot kaki memiliki nilai signifikansi tertinggi untuk kemampuan passing atlet. $(\beta=0,6, p<0,05)$. Persentase otot tungkai dan tingkat konsentrasi adalah faktor fisik dan kognitif yang memiliki peran lebih besar dalam kemampuan passing atlet futsal Jatinangor.
\end{abstract}

Kata kunci: Faktor fisik, faktor kognitif, futsal, passing

Corresponding Author: Leonardo Lubis, Department of Biomedical Sciences Faculty of Medicine Universitas Padjadjaran, Jalan Raya Bandung-Sumedang Km.21, Jatinangor, Sumedang, Indonesia, Email: btpualam@gmail.com 


\section{Introduction}

Exercise is a form of physical activities that is defined by WHO as a planned, structured, and repetitive form of physical activities aiming at enhancing or maintaining one or more components of physical health or fitness. Sports is a competitive form of exercise that includes various kinds of sports, including Futsal. Futsal is a different kind of soccer that is played on a smaller field and is usually performed in an indoor field. Futsal is one of the fastest and growing sports in the world and, according to FIFA, futsal is declared as the indoor sports with the fastest development in the world. ${ }^{1}$

Futsal athletes are influenced by several factors that play a role in their ability to play futsal. There are 4 main factors affecting the ability of athletes, including futsal athletes, to play well. These factors are technical ability, tactics or strategy, physiological or physical conditions, and mental or psychological conditions.2 Physical and mental factors influence the ability of athletes to execute their technical skills and tactical instructions in the game.

There are several basic techniques needed by futsal athletes to play futsal. The four basic techniques that must be mastered well by futsal athletes include passing, dribbling, shooting, and control. ${ }^{3}$ The physical and cognitive factors influence how well these athletes can perform these basic futsal techniques.

Anthropometric profile of an athlete, including futsal athletes, is one of the physical factors that determines the athlete's technical abilities. Physical factors, such as muscle mass and fat mass, will help futsal athletes to maximize their technical ability to play futsal. ${ }^{3}$

Cognitive ability is one of the mental abilities influencing athletes' performance. It also plays a large role in the performance of futsal athletes in carrying out their games. Cognition is the process of getting, storing, processing, and using information. Cognitive ability can also be defined as the ability of a person to obtain, store, process, and use the information received. 4

Futsal athletes play futsal in the context of sports. It means that they have the ultimate goal of winning and achieving titles and trophies as much as possible, because an athlete's main goal is to achieve victories. ${ }^{5}$ The world of sports, including futsal, has numerous competitions, both at local, national, and international level, as well as from various age categories. ${ }^{6}$ Increasing athletes' performance is the best way to gain a higher number of victories. The ability to perform good basic futsal techniques can be a good first step to improve the performance of athletes in the field. Improving these abilities, of course, must be supported by improvement of factors influencing them, including the physical and cognitive factors of the athletes.

This study aimed to analyze the effect of physical and cognitive factors on passing abilities of Universitas Padjadjaran futsal athletes and to determine which physical and cognitive factors that have a greater influence on passing abilities.

\section{Methods}

This study was a cross-sectional analytical study approved by the Health Research Ethics Committee Faculty of Medicine Universitas Padjadjaran Number: 1017/UN6.KEP/EC/2018 on futsal athletes currently listed as the members of the Faculty of Medicine Futsal unit and La Coruna FC amateur futsal club. Sampling was performed randomly with the minimum number of samples needed of 20 athletes $(r=0.5)$. The inclusion criteria in this study were Faculty of Medicine Futsal athletes and athletes listed as members of the La Coruna FC club who attended routine training at least once a week and aged 17-23 years. Subjects who were willing to take part in the study were 33 people, consisting of 23 men and 10 women.

The study was conducted on Saturday, November 10, 2018, at the C6 Building, Faculty of Medicine, Universitas Padjadjaran at 08.00 to 12.00. Subjects were asked to have breakfast a maximum of 1 hour before the study took place.

The physical factors of futsal athletes were measured using 2 instruments, a calibrated microtoise for height measurement and Bioimpedance Analysis, Karada Body Composition Scan for measurements of other physical factors such as body mass index (BMI), percentage of total muscle mass, percentage of foot muscle mass, percentage of total body fat mass, and percentages of feet subcutaneous fat. ${ }^{7}$ Data were recorded in the form of a numerical scale.

Cognitive factors measured were attention, short term memory, and spatial ability. Attention was measured using the Grid Concentration Test ${ }^{8}$ using 10x10 boxes containing numbers 00 to 99 . Participants were asked to connect the smallest to the largest number as many as possible within a minute time frame. The biggest number that was successfully linked by the athlete is the recorded score. 
Short-term memory is measured using the Digit Span test. ${ }^{9}$ This test is divided into 2 parts, Digit Span Forward test and Digit Span Backward test. The Digit Span Forward test was performed by asking the athlete to repeat the sequence of numbers read by the examiner. There were 8 items to be read. Correct answer was given a score of 2 while incorrect answer was given a score of 0 . If the athlete was unable to answer the sequence of numbers with the same sum of number twice, the test was considered to be completed. The Span Backward digit test was performed by repeating the sequence of numbers mentioned by the examiner, but sorted in reverse. Eight questions that were read by examiner. Athletes were given a score of 2 when answering correctly and 0 when answering incorrectly. If the athlete was unable to answer the sequence of numbers with the same sum of number twice, the test was considered completed. The results of the two tests were then combined and the total score were recorded.

The spatial ability tests were carried out using the spatial ability test sheet adopted from Paul Newton. ${ }^{10}$ Participants were asked to answer 45 items consisting of form matching, group rotation, combining shapes, cube display in 3D, 2D shapes, 3D shapes, and map. Participant was given 20 minutes to answer the question. The questionanswered correctly received a score of 1 while the one answered incorrectly received a score of 0 . The total score was gained from summing up the score sobtained.

The test of the basic futsal techniques covered passing technique. The passing test was carried out with 30 seconds pass and stop tests. Athletes were asked to pass to the wall as much as possible from a distance of 2 meters for 30 seconds. Every time before passing the ball, the participant must control the ball first using the kicking foot.
The number of passing done was calculated and recorded.

All data obtained in this study were processed using the IBM statistical product and service solution (SPSS) software and were analyzed using linear regression. Normality test and descriptive data test were performed before analysis. The normality test was carried out on variables using the Shapiro-Wilk test. Variables with normal data distribution was processed using Pearson test analysis while variables with abnormal data distribution was processed using Spearman test analysis. Variables with significant values $(p<0.25)$ were then analyzed using linear regression analysis.

\section{Results}

Results of this study listed in Table 1 present the characteristics of futsal athletes. After bivariate analysis was performed it was revealed that the total of physical body fat, subcutaneous fat, total body muscle, and subcutaneous muscle foot variables met the criteria for entry in linear regression analysis. while for cognitive factor variables, only the concentration fulfilled the criteria to enter the stages of linear regression analysis $(\mathrm{p}<0.25)$.

In the multiple linear regression analysis, it was revealed that the physical factors that meet the classic assumption test requirements were the percentage of leg muscle and total body fat. Subcutaneous leg muscle was shown to have a significant influence on the passing ability of futsal athletes $(\beta=0.600, p<0.05)$ while the total body fat and attention presented an insignificant level of influence ( $p>0.05$; Table 4).

It was discovered that the physical factor that had the greatest positive influence on the passing

Table 1 Characteristic of Participants

\begin{tabular}{lcccc}
\hline & n & Median & Minimum & Maximum \\
\hline Total body fat (\%) & 33 & 20.2 & 11.7 & 31.2 \\
Leg subcutaneous fat (\%) & 33 & 21.6 & 12.8 & 39.2 \\
Total body skeletal muscle (\%) & 33 & 33.7 & 25 & 37.6 \\
Legs skeletal muscle (\%) & 33 & 51 & 17 & 54.6 \\
BMI (kg/m ${ }^{2}$ ) & 33 & 22.1 & 27 & 26 \\
Spatial ability & 33 & 35 & 10 & 40 \\
Short-term memory & 33 & 20 & 5 & 28 \\
Attention & 33 & 10 & 12 & 20 \\
Passing ability & 33 & 21 & 23 \\
\hline
\end{tabular}


Table 2 Bivariat Analysis of Physical Factors towards Passing Ability

\begin{tabular}{|c|c|c|c|c|c|c|}
\hline & & $\begin{array}{l}\text { Total Body } \\
\text { Fat }\end{array}$ & $\begin{array}{c}\text { Legs } \\
\text { Subcutaneous } \\
\text { Fat }\end{array}$ & $\begin{array}{l}\text { Total Body } \\
\text { Muscle }\end{array}$ & $\begin{array}{l}\text { Legs } \\
\text { Muscle }\end{array}$ & BMI \\
\hline \multirow{3}{*}{ Passing Ability } & $\begin{array}{l}\text { Spearman } \\
\text { Correlation }\end{array}$ & -.716 & -.723 & .734 & .735 & .256 \\
\hline & p-Value & $.000 *$ & $.000^{*}$ & $.000^{*}$ & $.000^{*}$ & .252 \\
\hline & $\mathrm{N}$ & 33 & 33 & 33 & 33 & 33 \\
\hline
\end{tabular}

*P-value is significant $(\mathrm{P}<0.25)$

Table 3 Bivariat Analysis of Cognitive Factors towards Passing Ability

\begin{tabular}{llccc}
\hline & & Short-term Memory & $\begin{array}{c}\text { Spatial } \\
\text { Ability }\end{array}$ & Attention \\
\hline \multirow{3}{*}{ Passing Ability } & Spearman Correlation & .155 & .150 & .245 \\
& & & & $.169^{*}$ \\
& $\mathrm{p}$-Value & .390 & .404 & 33 \\
\hline
\end{tabular}

${ }^{*}$-value is significant $(\mathrm{p}<0.25)$

ability of futsal athletes was the percentage of leg muscle (Table 2) while the cognitive factor that had the strongest positive influence on the passing ability of futsal athletes was attention. (Table 3).

\section{Discussion}

The results of this study indicate that good leg muscle strength is an essential and influential factor for futsal athletes to execute passing. The percentage of skeletal muscles in the legs has a higher positive significance compared to other factors. It means that having legs with high percentage muscle in futsal athletes will produce necessary kick power needed for athlete to make a pass, so that the result on passing accuracy can be optimum.

Other results indicated that the concentration ability of futsal athletes had the greatest significance compared to other cognitive factors. Athletes who have a good level of concentration tend to have a better ability to determine to which direction he will pass the ball. ${ }^{11}$

The passing ability in futsal is one of the basic technique abilities that should be mastered well by every futsal athlete. ${ }^{3}$ Passing can be done with all sides of the foot according to the needs. ${ }^{12}$ Generally, passing is done with the inner side of sole. In addition, kick power is also important as it relates to the distance that can be traveled by the ball to get to the player who is supposed to receive it. ${ }^{11}$

In futsal, the most dominant type of passing is short passing. ${ }^{11}$ General passing distance in futsal is less than 10 meters. ${ }^{13}$ This passing ability in futsal is usually closely related to ball control ability. It is well understood that the type of passing combination that is most frequently performed in futsal is a stop-pass combination, which is a type of passing between players with

Table 4 Regression Analysis of Physical and Cognitive Factors towards Passing Ability

\begin{tabular}{lcccc}
\hline \multicolumn{1}{c}{ Predictors } & $\boldsymbol{\beta}$ Value & P Value & \multicolumn{2}{c}{ Confidence Interval } \\
\hline Physical factors & & & Minimum & Maximum \\
Legs muscle & .600 & $.000^{*}$ & .096 & 0.504 \\
Total body fat & -.249 & .221 & -.405 & .098 \\
Cognitive factors & & & & \\
Attention & .314 & .076 & 0.33 & 0.637 \\
\hline
\end{tabular}

*P-value is significant $(\mathrm{P}<0.05)$ 
a pause to control the ball briefly before passing the ball again. ${ }^{13}$

Accuracy is the most important thing that needs to be considered in passing. This is because the purpose of passing is to deliver the ball to teammates. Kicking accuracy when passing the ball is influenced by some factors such as kicking technique, foot placement, kicking foot movements, and contact between feet and balls. ${ }^{14}$ The kicking technique in futsal varies but generally, the technique used the inside part of foot to kick. Kicking with the inner foot is known to have the most optimal performance for combining accuracy and kicking power in playing futsal. ${ }^{11}$

The most influential kicking factor to produce kicking power is muscle strength with leg muscles as the most important muscle as futsal predominately uses legs. ${ }^{15}$ Futsal is also a high-intensity sport requiring the body to work with high aerobic and anaerobic pathway needs. ${ }^{15}$ Futsal athletes also perform repeated sprint runs in a match that requires leg muscle strength. Increasing and maintaining excellent leg muscle strength is certainly a necessity for futsal athletes. ${ }^{16}$

Kicking the ball when passing also requires sufficient kicking power from the leg muscles. ${ }^{13}$ This is because the passing distance also determines the accuracy of the passing performed by futsal athletes. ${ }^{14}$ If the direction of the passing is accurate but the power is not sufficient, the ball will not reach its destination.

Passing performance is also influenced by cognitive factors. ${ }^{5}$ Cognitive factors that affect passing abilities are decision making ability and attention level. ${ }^{2,5}$ Attention is the concentration level of mental activity that allows a person to capture or receive a portion of the current information available from sources in the form of sensory systems and memory centers. ${ }^{4}$ Sports athletes, including futsal athletes, need this attention process in various activities. ${ }^{5}$ Basic playing technique practice, for example, requires a certain level of attention to be able to learn motoric movements of a sports technique. The amount and precision of information a obtained is another example of attention function. ${ }^{4,5}$

With good attention, futsal athletes can determine the right passing decision. As a result, optimum passing accuracy can be achieved. Conversely, with poor attention, the athlete will not be able to optimally determine the target of passing. As a result, the accuracy of the passing will also not be optimum.

The limitation of this study is the limited research time. In addition, the level of stress experienced by athletes were not examined during the study and other factors such as fatigue and poor physical condition were also not examined. Further studies need to be carried out by considering those matters. Studies with a larger scope also need to be conducted to examine the effect of spatial ability, as a cognitive factor, on athlete's passing ability because it is known to differ from results of previous studies. ${ }^{5}$

In conclusion, passing in futsal is a basic technique influenced by several factors, including physical and cognitive factors. The most dominant physical factor influencing passing ability of futsal athlete is the strength of the athlete's leg muscles while attention is the cognitive factor that plays a big role in the accuracy of passing. With this knowledge on the importance of passing skills for futsal athletes, it will be good to devise training programs that aim to improve these factors so that the passing ability of futsal athletes will be better.

\section{References}

1. Berdejo-del-fresno D. A review about Futsal. Am J Sport Sci Med. 2014;2(3):70.

2. Bangsbo J. Performance in sports- With specific emphasis on the effect of intensified training. Scand J Med Sci Sport. 2015;25:8899.

3. U Umar, Doewes M, Purnama SK. Analysis of factors and conditions anthropometry determinant dominant performance athletes futsal. IJPNPE 2017;2(2):249-51.

4. Matlin MW. Cognition. an introduction to theories of personality. $8^{\text {th }}$ ed. Taiwan: John Wiley \& Sons; 2013.

5. Yarrow K, Brown P, Krakauer JW. Inside the brain of an elite athlete: the neural processes that support high achievement in sports. Nat Rev Neurosci. 2009;10(8):585-96.

6. Moore R, Bullough S, Goldsmith S, Edmondson L. A systematic review of futsal literature. Am J Sports Sci Med. 2014; 2(3):108-16.

7. Gupta SRN. Body composition analysis of staff members of college using bioelectrical impedance analysis method. Int J Chem Eng Appl. 2014;5(3):259-65.

8. Kent S, Devonport TJ, Lane AM, Nicholls W, Friesen AP. The effects of coping interventions on ability to perform under pressure. J Sports Sci Med. 2018;17(1):40-55.

9. Fitzpatrick AL, Rapp SR, Luchsinger J, Alonso A, Gottesman R, Lee H, etal.Sociodemographic 
correlates of cognition in the multi-ethnic study of atherosclerosis (MESA). Am J Geriatr Psychiatry. 2016;23(7):684-97.

10. Shiota K, Tokui A. Audiospatial cognitive ability of visually impaired athletes in static and dynamic spatial cognitive tasks. J Phys Ther Sci. 2017;29(11):1981-6.

11. Ren DM. Research on the passing characteristics of futsal game. Journal of Beijing University of Physical Education. 2013;36(1):123-6.

12. Lhaksana J. Taktik dan strategi futsal modern. Jakarta: Be Champion; 2011.

13. Katis A, Giannadakis E, Kannas T, Amiridis I, Kellis E, Lees A. Mechanisms that influence accuracy of the soccer kick. J Electromyogr Kinesiol. 2013;23(1):125-31.

14. Dal Pupo J, Detanico D, Ache-Dias J, Santos SG. The fatigue effect of a simulated futsal match protocol on sprint performance and kinematics of the lower limbs. J Sports Sci. 2017;35(1):81-8.

15. Galy O. Anthropometric and physiological characteristics of Melanesian futsal players : a first approach to talent identification in Oceania. Biol Sport. 2015;32(2):135-41. .

16. Naser N, Ali A, Macadam P. Physical and physiological demands of futsal. J Exerc Sci Fit. 2017;15(2):76-80. 